\title{
IMPLEMENTASI NILAI KEJUJURAN PADA ANAK USIA DINI MELALUI MEDIA ULAR TANGGA
}

\author{
Endah Hendarwati ${ }^{1}$, Wahono ${ }^{2}$, Aris Setiawan ${ }^{3}$ \\ ${ }^{1,2,3}$ Program Studi PG PAUD, Fakultas Keguruan dan Ilmu Pendidikan \\ ${ }^{2}$ wahono@fkip.um-surabaya.ac.id
}

\begin{abstract}
ABSTRAK
Penelitian ini bertujuan untuk mendeskripsikan perkembangan kejujuran anak melalui media ular tangga. Penelitian ini dilakukan pada PAUD Cahaya Jembatan Merah Suarabaya. Metode yang digunakan pada penelitian ini adalah penelitian kualitatif. Subjek pada penelitian ini adalah anak PAUD Cahaya jemabaran Merah Surabaya, yang terdiri dari 9 anak. Analisis data yang digunakan pada penelitian ini adalah analisis data kualitatif deskriptif. Teknik pengumpulan data dengan lembar observasi, wawancara, dan dokumentasi. Dari hasil penelitian diketahui bahwa dari kegiatan pembelajaran dengan menggunakan media ular tangga, anak mampu merawat dan menjaga benda milik bersama, Anak terbiasa berkata jujur, mau mengakui kesalahan, dan mau minta maaf bila salah, dan memaafkan teman yang berbuat salah. Sehingga dapat disimpulkan bahwa implementasi nilai kejujuran melalui media ular tangga sudah sesuai dengan teori dan praktik di lapangan.
\end{abstract}

Kata kunci: Kejujuran, Media Ular Tangga

\begin{abstract}
This study aims to describe the development of children's honesty through the media ular tangga. This research was conducted on PAUD Cahaya Jembatan Merah Surabaya. The method used in this research is qualitative research. Subjects in this study are children PAUD Cahaya Jembatan Merah Surabaya, which consists of 9 children. Data analysis in this research used descriptive qualitative data analysis. Data collection techniques with observation sheets, interviews, and documentation. From the results of research known that from learning activities by using media ular tangga, Children are able to care and keep things together, Children are accustomed to tell the truth, want to admit mistakes, and want to apologize if wrong, and forgive friends who do wrong. So it can be concluded that the implementation of honesty through the media ular tangga is in accordance with the theory and practice in the field.
\end{abstract}

Keywords: Honesty, Media Ular Tangga 


\section{PENDAHULUAN}

Pada era globalisasi ini bayak elemen masyarakat mengkritik pendidikan Indonesia, pendidikan di Indonesia bisa dikatakan belum berhasil membangun karakter generasi bangsa. Para ahli mengidentifikasi pendidikan di Indonesia gagal karena banyak lulusan sekolah mulai dari pendidikan dasar yaitu SD hingga perguruan tinggi, dari sarjana sampai gelar profesor yang memiliki pikiran yang cerdas tetapi memiliki karakter moral dan kultural yang lemah, tidak bermoral dan tidak jujur. Karakter jujur merupakan harapan dan karakter yang harus di tanamkan pada masyarkat bangsa kita . Hal ini dengan alasan karena nilai kejujuran merupakan yang paling utama dan mendasar dalam kehidupan bermasyarakat, dengan karakter tersebut kita dapat membedakan manusia dari makhluk lain. Oleh karena itu penanaman nilai-nilai kejujuran ditanamkan kepada anak sejak usia dini dengan berbagai metode pembelajaran.

Anak usia dini adalah anak yang berada pada rentan usia 0-6 tahun (UndangUndang Sisdiknas tahun 2003). Pada masa ini seorang anak akan tumbuh dan berkembang sangat pesat, orang tua tidak bisa menggantikannya pada masa- masa yang mendatang. Anak usia dini cepat sekali berkembang di semua aspek pengembangan termasuk aspek moral yang didalamnya mencakup nilai kejujuran. Orang tua dan guru mempunyai kewajiban harus mendidik anak berusia 5-6 tahun agar memiliki perilaku yang baik, dan menjadikannya anak yang berkarakter kuat dan tangguh, nilai karakter yang perlu ditanamkan berkaitan dengan pendidikan karakter nilai kejujuran. Anak sejak usia dini harus ditanamkan jujur (tidak berbohong), mengenal mana yang benar dan mana yang salah, mengenal mana yang baik dan mana yang buruk dan mengenal mana yang diperintah dan mana yang dilarang (Hidayatullah, 2010: 32).

Kejujuran merupakan salah satu hal penting yang digunakan dalam membina hubungan dengan diri sendiri dan orang lain. Menurut Hidayatullah (2010: 33) kejujuran merupakan bagian dari nilai karakter yang harus ditanamkan pada anak sedini mungkin karena nilai kejujuran merupakan nilai kunci dalam kehidupan. Kita dapat membangun landasan yang kokoh apabila pendidikan nilai kejujuran dapat dilakukan 
secara efektif .

Kejujuran merupakan hal yang penting dalam kehidupan manusia, tetapi dalam pelaksanaannya nilai kejujuran merupakan suatu yang sulit dilakukan, seseorang selalu mudah tergoda untuk melakukan kebohongan dan kecurangan disebabkan ingin mendapatkan sesuatu lewat jalan pintas. Kejujuran merupakan sebuah sifat, sikap atau kebiasaan, sehingga kejujuran tidak bisa dibentuk secara instant, tapi harus melalui proses pembiasaan diri dalam waktu yang lama. Penanaman nilai kejujuran dapat dilakukan melalui pendidikan formal di sekolah, yaitu mulai dari Pendidikan Anak Usia Dini. Langkah dalam membangun nilai kejujuran pada anak usia dini dapat dilakukan dengan terlebih dahulu harus dikenalkan konsep atau pemahaman kepada anak usia dini tentang nilai kejujuran. Penanaman nilai- nilai kejujuran pada anak usia dini dapat dilakukan dengan dua pendekatan yaitu pendekatan kognitif dan pendekatan belajar sosial. Pendekatan kognitif digunakan untuk menumbuhkembangkan pengetahuan dan kesadaran anak terhadap pentingnya bersikap jujur Pendekatan belajar sosial yang dilakukan lewat percontohan dan penguatan digunakan untuk membiasakan anak melakukan perbuatan jujur lewat peniruan dan pembiasaan. Kedua pendekatan ini sebaiknya dipahami dan digunakan para orang tua, guru, dan para orang dewasa lainnya.

Orang tua dalam membentuk karakter anak agar anak menjadi orang jujur salah satu cara dengan berperilaku jujur kepada anak usia dini. Jika kita sering berbohong, maka anak dengan sendirinya akan mengartikan bahwa berperilaku tidak jujur merupakan hal yang wajar dan dibenarkan (Isna, 2012: 25). Penanaman nilai kejujuran sejak usia dini juga merupakan salah satu cara untuk menanggulangi tindak pidana korupsi. Anak usia dini berada dalam masa keemasan atau golden age, Anak usia dini yang masih berada dalam masa keemasan ini dapat berkembang secara maksimal dalam semua aspek perkembangannya diantaranya aspek perkembangan moral yang di dalamnya mencakup pendidikan karakter nilai-nilai kejujuran. Proses penanaman nilai kejujuran pada anak dapat dilakukan dengan berbagai cara seperti transfer pengetahuan dan pemahaman, serta keteladanan.

Menurut Suyanto (2010) dalam hasil penelitiannya menunjukkan bahwa sekitar $50 \%$ variabilitas kecerdasan sudah terjadi saat anak berusia 4 tahun. Peningkatan $30 \%$ berikutnya terjadi pada usia 8 tahun, dan 20 
\% sisanya pada pertengahan atau akhir dasawarsa kedua. Oleh karena itu masa usia dini merupakan masa yang paling baik untuk menanamkan Karakter nilai kejujuran. Penanaman karakter sejak usia dini sangat berguna untuk membentuk generasi muda yang berkualitas ke depannya. Salah satu cara menanamkan nilai kejujuran pada anak usia dini dengan menggunakan permainan ular tangga. Permainan ular tangga dapat menanamkan nilai kejujuran pada anak lebih efektif, karena dengan bermain ular tangga anak akan lebih tertarik dan dapat mengingat lebih lama.

\section{Pengertian Kejujuran.}

Menurut Ibung (2009:69) kejujuran merupakan suatu kemampuan untuk mengakui perasaan atau pemikiran atau juga tindakan seseoarang kepada orang lain. Kejujuran menjadi penting karena dengan mengakui apa yang dia pikirkan, ia rasakan, dan dia lakukan sebagaimana adanya seseorang dapat terhindar dari rasa bersalah yang timbul akibat kebohongan yang dilakukan.

Kemendiknas (Wibowo, 2012:71) mengungkapkan bahwa nilai-nilai pendidikan karakter yang perlu diinternalisasikan salah satunya adalah kejujuran. Jujur adalah perilaku yang berdasarkan pada upaya menjadikan dirinya sebagai orang yang selalu dapat dipercaya dalam perkataan, tindakan dan pekerjaan.

Siapa yang memiliki perilaku kejujuran pintu kebaikan akan terbuka, kemudian siapa yang berperilaku tidak jujur lajur kejahatan juga terbuka lebar (Sudewa. E, 2011: 83). Pendapat diatas dapat diartikan bahwa anak yang suka melakukan hal-hal yang tidak jujur akan mengalami kerugian sendiri, hal ini terlihat dalam kualitas hasil pekerjaannya baikyang jujur dan tidak jujur. Setiap orang memiliki karakter yang unik, masing-masing mempunyai karakter yang berbeda tidak sama antara satu dengan yang lainya. Setiap karakter memiliki ciri yang berbeda, baik karakter jujur, tanggung jawab, dan lain- lainya Orang yang memiliki karakter jujur dicirikan oleh perilaku berikut (Kusuma, dkk, 2013: 17):

a. Jika bertekad (inisiasi keputusan) untuk melakukan sesuatu, tekadnya adalah kebenaran dan kemaslahatan.

b. Jika berkata tidak berbohong (benar apa adanya).

c. Jika ada kesamaan antara yang dikatakan hatinya dengan apa yang dilakukanya. 


\section{Pembiasaan Kejujuran}

Menurut Sadewa (2011: 84) melatih kejujuran pada anak tidaklah sulit hal utama yang harus diketahui adalah konsep kepemilikan. Anak harus ditanamkan sejak usia dini apabila menginginkan kepunyaan orang lain haruslah meminta ijin kepada orang yang memiliki barang tersebut. Menanamkan nilai Kejujuran pada anak usia dini merupakan hal yang sangat penting dalam membentuk sikap dan perilaku anak di masa yang akan datang. Setiap orangtua selalu ingin anaknya mempunyai perilaku jujur, ketika anak berkata bohong orang tua akan shock dan berpikir keras untuk mengatasinya. Pada saat anak sudah mulai berbohong orang tua tidak diperbolehkan untuk marah. Orang tua maupun guru dapat menghadapi kebohongan anak usia dini tersebut dengan sikap rileks dan menganggapnya sebagai dongeng. Kebohongan pada anak merupakan hal yang normal bagi perkembangan moral pada anak. Orangtua tidak boleh memberikan hukuman pada anak ketika anak berbohong tetapi harus memberikan pengertian dan alasan untuk tidak berbohong. Orangtua harus menjelaskan pada anak apabila perilaku berbohong akan merugikan dirinya sendiri dan membuat orang lain tidak akan percaya pada yang telah dikatakan. Menurut Rahmah (2012:97) membiasakan jujur pada anak dapat dilakukan dengan:

a. Jamin Dia Aman Berkata Jujur Seorang anak akan merasa aman untuk berkata jujur, apabila semua orang disekitar anak kita dapat menghargai kejujuran yang dilakukan oleh anak tersebut. Tidak marah pada anak ketika anak telah mengakui kesalahannya, karena dengan anak mengakui kesalahanya ia akan berfikir bahwa kejujuran hanya akan berakibat negatif baginya dan sebaiknya kita mengucapkan terimakasih karena anak telah berkata jujur maka akan terbangun image positif pada anak.

b. Perilaku orangtua dan lingkungan pada anak yang teah berkata jujur akan mempengaruhi perilaku seorang anak. Apabila anak melakukan kesalahan dan berkata jujur orang tua memarahi anak tersebut maka anak akan merasa takut untuk berkata jujur. Memberi rasa aman kepada anak untuk berkata jujur dan penjelasan yang mudah tentang pentingnya kejujuran akan memberikan dorongan pada anak untuk tidak berkata bohong lagi.

c. Selain dengan memberikan rasa aman, orangtua dan lingkungan anak dapat menggunakan metode reward. Dengan memberikan penghargaan dan hadiah 
terhadap anak yang telah berperilaku jujur. Tetapi sebelum menentukan hadiah harus dilakukan kesepakatan terlebih dahulu hadiah akan diberikan jika anak telah berapa kali melakukan kejujuran. dengan pemberian hadiah akan menjadikan seorang anak menjadi bangga terhadap kejujuranya.

d. Tanamkan Bahwa Allah Maha

Melihat dan Maha Mendengar

Setiap anak pernah berbohong, tetapi ada anak yang berbohong karena situasi mendesak dan ada juga tang berbohong karena menjadikanya sebagai kebiasaan yang pada akhirnya anakn membawa kehancuran di masa depan anak tersebut. Mengatasi seorang anak yang berbohong tidaklah mudah, karena meneliti berbagai alasan dan penyebab yang mungkin mendorong seorang anak untuk berkata bohong

Ketidakjujuran anak merupakan pelanggaran atau kebohongan yang dilakukan oleh anak-anak. Menurut Hurlock $(1978,104)$ ketidakjujuran dalam berbagai bentuk merupakan pelanggaran.

Menurut Ibung (2009, 71) kebiasaan berbohong pada anak dapat dilakukan dengan beberapa bentuk yaitu:

a. Memutarbalikan keadaan.

b. Melebih-lebihkan, anak menceritakan sesuatu dengan mengombinasikan antara kebenaran dan khayalannya.

c. Membual, anak menceritakan sesuatu yang tidak ia lakukan atau tidak ia alami, dengan seolah-olah ia sendiri mengalami atau merasakanya.

d. Melepas tanggung jawab dengan melemparkan kesalahan diri sendiri pada orang lain termasuk di dalamnya adalah fitnah.

Ketidakjujuran atau berbohong yang dilakukan anak karena mereka punya alasan ingin menguji kemampuan diri, keinginan untuk memiliki kekuasaan atas dirinya sendiri, menutupi ketidaktahuanya bahwa ia telah berbuat sesuatu yang "buruk" atau tidak baik dan bentuk perlindungan diri, kurang parcaya diri. Kebohongan juga dilakukan dalam berbagai

bentuk yaitu memutarbalikan keadaan, melebih-lebihkan, membual, dan melepas tanggung jawab. 


\section{Penyebab Anak Tidak Jujur atau}

\section{Berbohong}

Berbohong pada anak prasekolah merupakan bagian dari masalah dalam aspek perkembangan moral. Konsep benar dan salah akan muncul pada anak usia 3-4 tahun (Rahmah, 2012: 43). Munculnya berbohong pada usia tersebut adalah proses membentuk kenyataan dengan apa yang dia inginkan. Alasan lain untuk anak berbohong adalah mereka merasa tidak berdaya menyembunyikan kebenaranya, dan menghindari hukuman dari orangtua dan lingkungan sekitar. Hal yang bersifat umum ketika seorang anak usia prasekolah berbohong tentang sesuatu, tetapi sebagai orang-orang disekitarnya sebaiknya memperhatikan penyebab mengapa anak berbohong. Menurut Ibung (2009, 73) alasan anak untuk tidak jujur atau berbohong adalah sebagai berikut:

a. Ingin menguji kemampuan diri. b. Menghindar dari hukuman orangtuanya.

c. Cara ini digunakan untuk melupakan sesuatu yang tidak menyenangkan yang pernah dialami. Rahmah (2012: 44) juga berpendapat

ada beberapa penyebab seorang anak berbohong atau melakukan tindakan tidak jujur adalah sebagai berikut:

a. Anak berbohong untuk melihat reaksi lawan bicaranya, yang biasanya dalam hai ini adalah orang tuanya.

b. Berbohong untuk membesar- besarkan dirinya, yang sengaja dilakukan untuk meningkatkan rasa percaya diri di mata teman-temanya dengan harapan diperhitungkan di mata teman-temanya dan kelompok

c. Berbohong muncul pula karena imajinasinya yang berkembang pesat atau dapat dikatakan dusta putih. Padahal, sesungguhnya secara sadar dia tidak ingin berbohong. Dusta ini sering dilakukan oleh anak-anak prasekolah dan anak-anak kelas 1

SD. Setelah anak lebih dari kelas 1

SD maka tidak dapat dikatakan sebagai dusta putih lagi karena anak sudah dapat membedakan khayalan dan kenyataan

d. Berbohong juga dapat dilakukan anak untuk menutupi perbuatanya. Misalnya, ketika anak melakukan kesalahan anak langsung mencari kambing hitam untuk menutupi kesalahnya 
e. Berbohong juga dapat karena imitasi berbohong, di mana anak berbohong karena ingin meniru orang lain. Anak meniru tindakan-tindakan yang dilakukan oleh orangorang disekitarnya, terutama orangtua. Jadi

jangan heran jika orangtua pembohong maka anak juga pembohong.

f. Berbohong karena ingin pujian. Anak melakukan kebohongan karena ingin mendapat pujian dari orang-orang di sekitarnya, walaupun anak harus berbohong tentang hal-hal yang tidak dilakukanya

\section{Cara Orangtua Membentuk Karakter}

\section{Jujur Pada Anak}

Karakter kejujuran merupakan pilar penting dalam pembentukan perilaku seseorang. Karakter kejujuran ini harus ditanamkan sejak anak masih usia dini. Ada beberapa cara orangtua untuk membentuk karakter kejujuran (Isna, 2012: 37):

a. Hindari memberikan label "pembohong" kepada anak meskipun dia melakukan kebohongan.

b. Jangan Bohongi Anak

c. Jangan Memberi Contoh Berbohong

Berbagai cara yang dapat dilakukan orangtau untuk membentuk perilaku kejujuran pada anak mulai dari tidak memberikan labeling pada anak, karena pemberian labeling akan membentuk kepercayaan terhadap label tersebut. Kemudian jangan menanyakan sesuatu yang sudah diketahui jawabanya dan jangan tanyakan sesuatu yang anak tidak ingin menjawab. Selain itu jangan memarahi anak, ajarkan anak untuk berperilaku jujur

dan berikan pujian jika anak berperilaku jujur. Cara ini dapat membentu anak agar dapat berperilaku jujur dan akan membentuk generasi penerus bangsa selain itu penanaman nilai kejujuran dapat dilakukan dengan penggunaan media dalam pembelajaran.

Selain itu Rahmah (2012:99) juga menjelaskan ada bebrapa larangan yang tidak boleh dilakukan orangtua dalam membentuk sikap jujur pada anak:

a. Jangan Memojokkan Anak. b. Jangan Emosi

\section{Indikator-indikator Jujur AUD}

Berdasarkan pedoman pendidikan karakter pada pendidikan anak usia dini oleh direktorat pembinaan pendidikan anak usia dini, direktorat jenderal pendidikan anak 
usia dini, nonformal, dan informal, kementrian pendidikan nasional (2012) terdapat sembilan indikator untuk nilai atau karakter kejujuran yaitu:
a) Anak mengerti mana milik pribadi dan milik bersama
b) Anak merawat dan menjaga benda milik bersama
c) Anak terbiasa berkata jujur
d) Anak terbiasa mengembalikan benda yang bukan miliknya
e) Menghargai milik orang lain f) Mau mengakui kesalahan
g) Mau meminta maaf dan memaafkan teman yang berbuat salah
h) Menghargai keunggulan orang lain
i) Tidak menumpuk mainan atau makanan untuk diri sendiri.

\section{Media Pembelajaran}

Menurut bahasa, media berasal dari kata/bahasa latin dan merupakan bentuk jamak dari kata medium, yang secara harfiah berarti perantara atau pengantar. Media adalah perantara atau pengantar pesan dari pengirim ke penerima pesan (dalam Sanjaya, 2006: 132) Sedangkan menurut National Education Association (NEA), media sebagai segala benda yang dapat dimanipulasi, dilihat, didengar, dibaca atau dibicarakan beserta instrument yang dipergunakan untuk kegiatan tersebut. Gagne (dalam Arief Sadiman dkk, 2009) menyatakan bahwa media adalah berbagai jenis komponen dalam lingkungan mahasiswa yang dapat merangsang mahasiswa untuk belajar.

Media pembelajaran dapat menyederhanakan materi pembelajaran, mendekatkan dengan mahasiswa dan mengongkritkan konsep yang akan disampaikan oleh dosen. Media dapat dijadikan sebagai jembatan sebelum mahasiswa akan melakukan praktik. Peneliti beranggapan bahwa mahasiswa memerlukan media kreatif yang dapat mengaktifkan atau melibatkan partisipasi mahasiswa secara langsung dan bukan hanya melalui power pointsaja (menurut Septiana Pradina. 2009)

Dari uraian diatas dapat disimpulkan bahwa media pembelajaran adalah benda atau alat yang digunakan untuk menyalurkan pesan sehingga dapat merangsang pikiran, perasaan, perhatian dan kemauan mahasiswa, mengefesiensikan, mengefektifkan proses dan hasil belajar, dan dapat mendorong terjadinya proses belajar pada diri mahasiswa. Penggunaan media secara kreatif akan mengakibatkan mahasiswa belajar lebih banyak. 


\section{Fungsi Media Pembelajaran}

Media pembelajaran mempunyai beberapa fungsi yang dapat kita manfaatkan sebelum Proses Belajar Mengajar(PBM) berlangsung. Menurut Hamim (2011: 80) sebelum kita membuat sebuah media pembelajaran kita harus mengetahui dahulu konsep abstrak dan konkrit dalam pembelajaran. Karena proses belajar mengajar hakekatnya adalah proses komunikasi, penyampaian pesan dari pengantar dan penerima. Adapun fungsi media pembelajaran adalah sebagai berikut. a. Media pembelajaran dapat mengatasi keterbatasan pengalaman yang dimiliki oleh para peserta didik. Pengalaman peserta didik berbedabeda, tergantung dari faktor-faktor yang menentukan kekayaan pengalaman anak, seperti ketersediaan buku, kesempatan

melancong, dan sebagainya. Media pembelajaran dapat mengatasi hal tersebut. Jika peserta didik tidak mungkin dibawa ke obyek langsung, maka obyeknya lah yang di bawa ke peserta didik. Obyek dimaksud adalah dalam bentuk nyata, miniatur, model, maupun bentuk-bentuk gambar yang dapat disajikan secara audio visual dan audial.

b. Media pembelajaran dapat melampaui batasan ruang kelas.

c. Media pembelajaran memungkinkan adanya interaksi langsung antara peserta didik dengan lingkunganya.

d. Media menghasilkan keseragaman pengamatan.

e. Media dapat menanamkan konsep dasar yang benar, konkrit, dan realistis.

f. Media dapat membangkitkan keinginan dan minat baru.

g. Media membangkitkan motivasi dan merangsang anak untuk belajar.

h. Media memberikan pengalaman yang integral/menyeluruh dari yang konkrit sampai dengan abstrak.

\section{Media Ular Tangga}

Permainan ular tangga merupakan kegiatan bermain, anak sesungguhnya belajar permainan (games) untuk mengeksploitasi dan merekayasa berbagai hal serta berinteraksi satu sama lain yang dapat dilakukannya dengan mengikuti aturan - aturan tertentu. Para pemain yang sama, bermain dengan meletakkan bidak pada papan permainan ular yang bertuliskan kata "Strat" selanjutnya tiap pemain mengocok dadu untuk menentukan berapa langkah yang harus dijalankan. Setelah berhenti di salah satu kotak, pemain dapat 
langsung menebak nama suatu aktivitas yang langsung,spontan, langkah permainan diatas dilakukan oleh pemain secara bergantian hingga berakhir, dilakukan dengan di kotak yang bertuliskan kata "Finish".

\section{METODOLOGI}

Penelitian dilakukan di PAUD Cahaya semester 2, pada semester genap 2016/2017. Subjek Penelitian ini adalah anak PAUD semester 2 yang berjumlah 9 anak dengan tingkat kemampuan heterogen. Untuk menganalisis data menggunakan interactive model yang dikemukakan Miles, terdapat tiga langkah yaitu data reduksi, penyajian data, dan penarikan kesimpulan. Data diperoleh dengan tiga teknik pengumpulan data yaitu wawancara, observasi, dan dokumentasi. Wawancara menggunakan jenis wawancara terstruktur karena peneliti sudah menyiapkan pertanyan-pertanyaan berkaitan dengan apa yang akan diteliti. Observasi yang digunakan menggunakan jenis observasi berperan serta karena peneliti ikut dalam

kegiatan pembelajaran tetapi tidak mengajar hanya melakukan pengamatan. Setelah data terkumpul dan dianalisis selanjutnya di uji keabsahannya dengan uji triangulasi, yang menggunakan jenis triangulasi teknik yang berarti menggunakan teknik yang berbedabeda untuk mengumpulkan data yang sama.

\section{HASIL DAN PEMBAHASAN}

Penelitian ini menggunakan teknik pengumpulan data wawancara, observasi, dan dokumentasi. Yang akan meneliti kejujuran anak. Indikator yang akan dibahas dalam penelitian ini diantaranya:

Tabel 4.1 Indikator Kejujuran

\begin{tabular}{|c|c|c|}
\hline $\begin{array}{l}\text { Variabel } \\
\text { Penelitian }\end{array}$ & Aspek & Indikator \\
\hline \multirow{4}{*}{$\begin{array}{l}\text { Karakter } \\
\text { Kejujuran } \\
\text { (Pedoman } \\
\text { Pendidikan Karakter } \\
\text { pada Pendidikan } \\
\text { Anak Usia Dini }\end{array}$} & \multirow{4}{*}{$\begin{array}{l}\text { Keadaan } \\
\text { yang keadaan } \\
\text { terkait dengan } \\
\text { ketulusan dan } \\
\text { kelurusan hati } \\
\text { berbuat benar }\end{array}$} & $\begin{array}{l}\text { 1. Anak merawat dan menjaga benda } \\
\text { milik bersama }\end{array}$ \\
\hline & & 2. Anak terbiasa berkata jujur \\
\hline & & 3. Mau mengakui kesalaha $\mathrm{n}$ \\
\hline & & $\begin{array}{l}\text { 4. Mau minta maaf bila salah, dan } \\
\text { memaafk an teman yang berbuat }\end{array}$ \\
\hline
\end{tabular}


Dari hasil penelitian yang menggunakan tiga teknik pengumpulan data dengan indikator di atas yang selanjutnya akan digunakan untuk uji kredibilitas dengan triangulasi teknik memperoleh data sebagai berikut:

Tabel 4.2 Kejujuran Anak

\begin{tabular}{|l|l|c|c|c|c|}
\hline \multirow{2}{*}{ No } & \multirow{2}{*}{ Nama Anak } & \multicolumn{5}{|c|}{ Indikator Kejujuran Anak } \\
\cline { 3 - 6 } & & $\mathbf{a}$ & $\mathbf{b}$ & $\mathbf{c}$ & $\mathbf{d}$ \\
\hline 1 & R1 & 4 & 3 & 3 & 3 \\
\hline 2 & R2 & 3 & 3 & 3 & 3 \\
\hline 3 & R3 & 4 & 4 & 3 & 4 \\
\hline 4 & R4 & 4 & 4 & 3 & 4 \\
\hline 5 & R5 & 4 & 4 & 4 & 4 \\
\hline 6 & R6 & 4 & 4 & 4 & 3 \\
\hline 7 & R7 & 3 & 3 & 3 & 3 \\
\hline 8 & R8 & 3 & 3 & 4 & 4 \\
\hline 9 & R9 & 3 & 3 & 3 & 3 \\
\hline
\end{tabular}

Berdasarkan hasil penelitian dari keempat indikator kejujuran banyak anak yang sudah memperoleh kriteria keempat yaitu berkembang sangat baik, yang lain memperoleh kriteria ketiga yaitu berkembang sesuai harapan. Jadi penanaman kejujuran anak menggunakan media ular tangga pada anak PAUD Cahaya berada dalam tahap berkembang sesuai harapan (3) dan berkembang sangat baik (4). Sudah tidak anak anak yang mendapatkan kriteria kedua (2) yaitu mulai berkembang dan kesatu (1) belum berkembang.

Strategi yang dilakukan guru dalam penanaman kejujuran anak di PAUD Cahaya adalah dengan penggunaan media yang menarik dalam pembelajaran yaitu media ular tangga. Dengan menggunaan media yang tepat dalam pembelajaran dapat merangsang anak untuk mengeksploitasi dan merekayasa berbagai hal serta berinteraksi satu sama lain yang dapat dilakukannya dengan mengikuti aturan- aturan tertentu dalam pembelajaran melalui bermain. Disamping itu, dengan media ular tangga guru juga 
memberikan pembiasaan kepada anak untuk berkata jujur. Seperti ketika anak melakukan kesalahan anak diajarkan untuk mengakui kesalahannya, anak juga dibiasakan untuk mau memaafkan kesalahan teman. Ketika dalam sebuah permainan ular tangga anak juga diajarkan untuk dapat merawat dan menjaga barang-barang milik bersama dengan baik contohnya media ular tangga yang digunakan untuk permainan tidak boleh dicoret-coret, disobek, dibuang serta menjaga perlengkapan (dadu dan papan ulartangga). Anak juga harus merapikan media ular tangga yang telah digunakan untuk disimpan kembali pada tempatnya. Hal ini sesuai dengan yang dikemukakan oleh Gerlach dan Ely (Sanjaya, 2010) menyatakan bahwa media adalah manusia, materi, atau kejadian yang membangun kondisi yang membuat siswa mampu memperoleh pengetahuan, keterampilan, atau sikap.

Jadi kesimpulannya penanaman kejujuran pada anak PAUD Cahaya

Surabaya sudah berada dalam tahap berkembang sesuai harapan. Berdasarkan analisis dari peneliti bahwa kejujuran pada anak usia dini perlu ditanamkan sejak dini melalui pembiasaan yang berulang-ulang. Disamping itu strategi pembelajaran di sekolah juga sangat mempengaruhi perkembangan kejujuran anak.

\section{PENUTUP}

Kejujuran merupakan suatu kemampuan untuk mengakui perasaan atau pemikiran atau juga tindakan seseoarang kepada orang lain. Kejujuran sangat penting ditanamkan pada anak sejak dini dalam membentuk sikap dan perilaku anak di masa yang akan datang. Kejujuran pada anak usia dini meliputi 1) anak mengerti mana milik pribadi dan milik bersama, 2) anak merawat dan menjaga benda milik bersama, 3) anak terbiasa berkata jujur, 4) anak terbiasa mengembalikan benda yang bukan miliknya, 5) menghargai milik orang lain, 6) mau mengakui kesalahan, 7) mau meminta maaf dan memaafkan teman yang berbuat salah, 8) menghargai keunggulan orang lain,dan 9) tidak menumpuk mainan atau makanan untuk diri sendiri.

Penanaman kejujuran pada anak usai dini dapat dilakukan melalui kegiatan pembelajaran yang menggunakan media yang menarik bagi anak. Sesui dengan pendapat Gagne yang menyatakan bahwa media adalah berbagai jenis komponen dalam lingkungan siswa yang dapat merangsang siswa untuk belajar. Salah satunya dapat merangsang anak untuk belajar kejujuran. Media tersebut salah satunya adalah media ular tangga. permainan dengan media ulartangga anak dapat mengeksploitasi dan 
merekayasa berbagai hal serta berinteraksi satu sama lain yang dapat dilakukannya dengan mengikuti aturan- aturan tertentu.

\section{REFERENSI}

Arikunto, Suharsimi. 2006. Prosedur Penelitian Suatu Pendekatan Praktik. Jakarta: Rineka Cipta.

Depertemen Pendidikan dan Kebudayaan. Kamus Besar Bahasa Indonesia. Jakarta: Balai Pustaka.

Dorothy L. Prestwich. 2003 Character Education in America's Schools. The School Community Journal, Volume 5, Issue 1. [March, 2003].

Hidayatullah, M Furqon. 2010. Pendidikan Karakter (Membangun Peradapan Bangsa). Surakarta: Yuma Pustaka.

Hurlock, Elizabeth B. 1978. Perkembangan Anak Jilid 2. Jakarta: Erlangga.

Ibung, D. 2009. Mengembangkan Nilai Moral pada Anak. Jakarta: PT Elex Media Komputindo Kelompok Gramedia.

Isna, Nurla. 2012. Mencetak Karakter Anak Sejak Janin. Yogyakarta: Diva Pers 